ISSN. 2621-9832

JURNAL MathEdu (Mathematic Education Journal) http://journal.ipts.ac.id/index.php/MathEdu

Vol. 4 No. 2 Juli 2021

\title{
APLIKASI PENDUKUNG PEMBELAJARAN MATEMATIKA PADA MASA COVID-19
}

\author{
Oleh : \\ *Putri Prastanti 1) , Anggun Badu Kusuma ${ }^{2)}$ \\ Fakultas Keguruan dan Ilmu Pendidikan, Universitas Muhammadiyah Purwokerto \\ Email: putriprass458@gmail.com ${ }^{{ }^{*}}$, anggun.badu@gmail.com ${ }^{2 *}$
}

\begin{abstract}
Abstrak
Arikel ini membahas tentang aplikasi pendukung pembelajaran matematika pada saat pandemi Covid19. Virus corona atau Covid-19 sedang melanda dunia pada saat ini, tak terkecuali Indonesia, turut serta mempengaruhi dunia pendidikan dimana proses belajar mengajar yang biasanya dilakukan secara tatap muka diruang kelas tetapi akibat pendemi Covid-19 proses belajar mengajar harus dilakukan melalui pembelajaran jarak jauh (daring). Media pembelajaran berbasis teknologi yang biasa digunakan adalah komputer. Untuk mendukung komputer kita memerluka softwere yaitu berupa aplikasi. Dengan adanya aplikasi diharapkan guru dan siswa lebih optimal dalam melangsungkan kegiatan belajar mengajar secara daring. Aplikasi penting untuk mendukung pembelajaran matematika yaitu karena matematika bersifat abstrak dan sering dianggap sulit oleh siswa. Beberapa aplikasi tersebut seperti Geogebra, Matlab, Wingeom, Microsoft Math 3.0 dan Microsoft Math 4.0. Penelitian ini bertujuan untuk membantu guru maupun siswa dalam menggunakan aplikasi - aplikasi yang mendukung pembelajaran matematika.
\end{abstract}

Kata kunci-Geogebra, Matlab, Wingeom, Microsoft Math 3, Microsoft Math 4.0

\begin{abstract}
This article discusses supporting applications for learning mathematics during the Covid-19 pandemic. The corona virus or Covid-19 is currently sweeping the world, including Indonesia, participating in influencing the world of education where the teaching and learning process is usually carried out face-to-face in classrooms due to the Covid-19 pandemic, the teaching and learning process must be done through distance learning (online ). Technology-based learning media that is commonly used are computers. To support computers, we need software in the form of applications. With the application, it is hoped that teachers and students will be more optimal in carrying out teaching and learning activities online. An important application to support mathematics learning is because mathematics is abstract and is often considered difficult by students. Some of these applications are Geogebra, Matlab, Wingeom, Microsoft Math 3.0 and Microsoft Math 4.0. This study aims to assist teachers and students in using applications that support mathematics learning.
\end{abstract}

Keywords-Geogebra, Matlab, Wingeom, Microsoft Math 3, Microsoft Math 4.0 
ISSN. 2621-9832

JURNAL MathEdu (Mathematic Education Journal) http://journal.ipts.ac.id/index.php/MathEdu

Vol. 4 No. 2 Juli 2021

\section{PENDAHULUAN}

Aplikasi merupakan program yang digunakan untuk menjalankan perintah - perintah yang bertujuan untuk mendapatkan hasil yang lebih akurat sesuai dengan tujuan pembuatan aplikasi tersebut. Aplikasi memiliki arti pemecahan masalah dengan menggunakan teknik pemrosesan data. Aplikasi berpacu pada komputansi maupun pemrosesan data yang diinginkan. Pengertian aplikasi secara umum merupakan alat terapan yang berfungisi khusus dan terpadu sesuai kemampuan yang dimilikinya. Aplikasi merupakan suatu perangkat komputer yang siap pakai sebagai user (Abdurahman \& Riswaya,2014).

Pada zaman yang semakin canggih ini, dimana perkembangan teknologi sangat pesat, aplikasi dapat membantu manusia di berbagai bidang salah satunya di bidang pendidikan. Salah satu manfaat aplikasi dibidang pendidikan yaitu sebagai media pembelajaran. Banyak sekali aplikasi yang bisa digunakan sebagai media pembelajaran seperti Google Class Room, Quipper School, Edmodo, Power Point dan lain sebaginya.

Matematika merupakan mata pelajaran yang diajarkan di semua jenjang (Cristomo, 2017). Melalui pembelajaran matematika dapat membantu siswa mengonstruksi pengetahuan melalui proses (Afifah, 2012). Matematika mempunyai karakteristik yaitu mempunyai objek kajian abstrak, bertumpu pada kesepakatan, berpola pikir deduktif, memiliki simbol yang kosong dari arti, memerhatikan semesta pembicaraan, dan konsisten dalam sistemnya. Karakteristik dan dampaknya didalam struktur matematika sangat penting dimiliki siswa dalam kehidupan seharinya baik sekarang ataupun pada masa yang akan datang (Hartinah \& Setiawan, 2013). Media pembelajaran yang digunakan harus interaktif dan up to date. Media pembelajaran berbasis teknologi yang biasa digunakan adalah komputer. Penggunaan komputer sebagai media, pembelajaran akan lebih menarik dan interaktif. (Akhmadan, 2017). Tetapi penggunaan komputer sebagai media pembelajaran itu saja belum cukup, kita membutuhkan softwere untuk menjalankannya. Softwere atau aplikasi akan memudahkan kita mengerjakan sesuatu sesuai dengan kegunaan atau tujuan aplikasi tersebut dibuat. Aplikasi berperan penting dalam pembelajaran matematika.

Seperti yang sudah kita semua ketahui, pandemi Covid-19 belum berakhir. Banyak dampak yang disebabkan oleh pandemi Covid-19 yang membuat resah seluruh negara. Salah satu bidang yang menerima pengaruh akibat pandemi Covid-19 adalah bidang pendidikan. Karena adanya pandemi Covid-19, pemerintah mengeluarkan Surat Edaran No. 4 tahun 2020 yang menyatakan bahwa sistem pembelajaran dilaksanakan dirumah (BDR). Pandemi Covid-19 terjadi di 219 negara di dunia. Oleh karena itu, pemerintah menghimbau masyarakat untuk melakukan pembatasan social (social distancing) dan menjaga jarak fisik (physical distancing), memakai masker dan selalu cuci tangan (Nengrum, et all., 2021). Karena pembelajaran dilakukan dirumah, pengajaran online darurat dioperasikan untuk sementara waktu tanpa desain kelas yang direncanakan tidak seperti pembelajaran online yang biasa dilakukan, baik peserta didik maupun guru mengalami kesulitan beradaptasi dengan kodisi seperti ini. Sekolah yang mengoperasikan pembelajaran secara online harus mempertimbangkan beberapa hal seperti media mudah digunakan, efektif, dan mengatasi berbagai faktor pembelajaran online (Handayani, 2020). E-learning merupakan model pembelajaran yang memanfaatkan fasilitas teknologi informasi dan komunikasi dan untuk mendukung proses pembelajaran jarak jauh selain e-learning ada beberapa pemanfaatan teknologi lainnya yang digunakan untuk meningkatkan proses belajar mengajar melalui pembelajaran jarak jauh diantaranya dengan menggunakan media komunikasi seperti WhatsApp, Google Class, YouTube, maupun Aplikasi zoom yang bisa mempertemukan guru dan siswanya secara virtual sehingga proses belajar mengajar bisa tersampaikan dengan baik (Pakpahan \& Fitriani, 2020).

Salah satu upaya untuk meningkatkan kualitas proses dan hasil pembelajaran siswa adalah dengan meningkatkan kemampuan guru dalam memanfaatkan aplikasi teknologi dalam proses pembelajaran dan penilaian hasil belajar (Marfuah, 2011). Literasi teknologi adalah kemampuan menggunakan aplikasi teknologi dan informasi secara efektif dan efisien dalam berbagai konteks, seperti dunia akademik dan pendidikan, pembelajaran dan pengajaran, penilaian pembelajaran, karier, serta kehidupan sehari-hari. (Intan, 2018). Saat ini proses pembelajaran tidak hanya di dalam kelas, tetapi juga menggunakan media digital,online, dan telekonferensi (Astini, 2019). Oleh karena itu, aplikasi sangat penting digunakan untuk mendukung kegiatan belajar mengajar.

Adapun manfaat pembelajaran yang dilakukan secara online yaitu materi yang sudah diajarkan bisa diberikan kembali. Namun pembelajaran yang dilakukan secara online juga mempunyai kekurangan anatara lain siswa tidak efektif, tidak semua orangtua siswa memiiki hardwere (laptop/handphone) dan pemberian materi tidak efektif (Nengrum, et all., 2021). Tujuan penulisan artikel ini adalah mendeskripsikan beberapa aplikasi matematika yang dapat membantu baik guru maupun siswa dalam menggunakan aplikasi tersebut.

\section{METODE PENELITIAN}


ISSN. 2621-9832

JURNAL MathEdu (Mathematic Education Journal) http://journal.ipts.ac.id/index.php/MathEdu

Vol. 4 No. 2 Juli 2021

Penelitian ini adalah penelitian kualitatif yaitu studi pustaka (library research), penelitian yang menghasilkan informasi berupa catatan dan data deskriptif yang terdapat di dalam teks yang diteliti. Dengan penelitian kualitatif, perlu dilakukan analisis deskriptif. Metode analisis deskriptif memberikan gambaran dan keterangan yang secara jelas, objektif, sistematis, analitis dan kritis mengenai aplikasi pendukung pembelajaran matematika. Pendekatan kualitatif yang didasarkan pada langkah awal yang ditempuh dengan mengumpulkan data-data yang dibutuhkan, kemudian dilakukan klasifikasi dan deskripsi.

\section{HASIL DAN PEMBAHASAN}

Macam - macam aplikasi pendukung pembelajaran matematika:

\section{Geogebra}

Geogebra adalah software yang menggabung geometri, aljabar, dan kalkulus ke dalam satu paket yang mudah digunakan untuk belajar dan mengajar matematika dari tingkat dasar hingga universitas, tersedia gratis di internet, dan telah diterjemahkan ke 36 bahasa (Hohenwarter, et all., 2008). Geogebra dapat bermanfaat dalam hal visibilitas dan pemikiran konseptual siswa (Akkaya, Tatar, dan Kagizmanli, 2011).

Tampilan dasar (interface) dalam software Geogebra Classic terdiri dari 3 tampilan utama yaitu (Putri, I. A., \& Purwaningsi, B. E, 2020):

a. Input Bar

Menu ini berfungsi untuk memasukkan / menginput suatu objek baru berupa titik, persamaan garis atau fungsi, dan lain sebagainya.

b. Algebra View

Menu ini memiliki fungsi untuk mengedit semua objek yang sudah di input sebelumnya. Caranya yaitu dengan double klik pada objek yang akan di edit.

c. Graphic View

Menu ini memiliki fungsi untuk menampilkan objek atau grafik yang sudah di input baik berupa titik, garis, maupun bangun ruang tertentu.

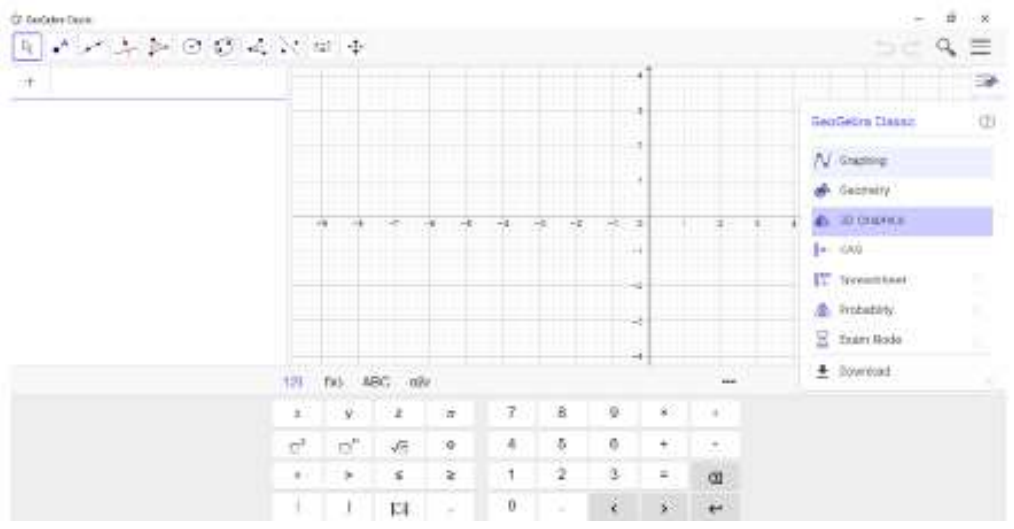

Gambar 1.1 Jendela uatama pada Geogebra Classic

Langkah - langkah membuat bangun ruang (Putri, I. A., \& Purwaningsi, B. E, 2020) :

a. Kubus

Pada gambar 1.1 ditunjukan bahwa tampilan awal setelah membuka software Geogebra Classic. Setelah itu kita diminta untuk memilih jenis grafik yang akan digunakan. Diantaranya terdapat pilihan untum membuat bangun 2 dimensi atau bangun datar, membuat bangun 3 dimensi atau bangun ruang serta yang lainnya. Kali ini jika mau membuat suatu bangun ruang maka pilih 3D Graphics maka akan muncul tampilan sebagai berikut. 
ISSN. 2621-9832

JURNAL MathEdu (Mathematic Education Journal) http://journal.ipts.ac.id/index.php/MathEdu Vol. 4 No. 2 Juli 2021

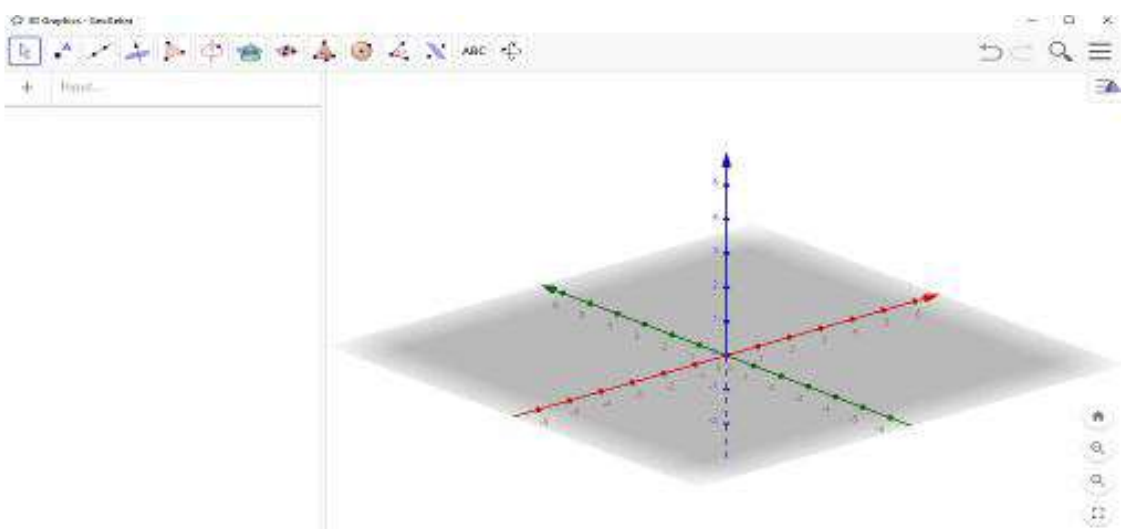

\section{Gambar 1.2 Tampilan 3D pada Geogebra Classic}

Selanjutnya kita misalkan akan membuat bangun ruang kubus, maka pilih $C u b e$. Setelah itu tentukan dua titik pada diagram Kartesius sehingga akan muncul bangun sebagai berikut

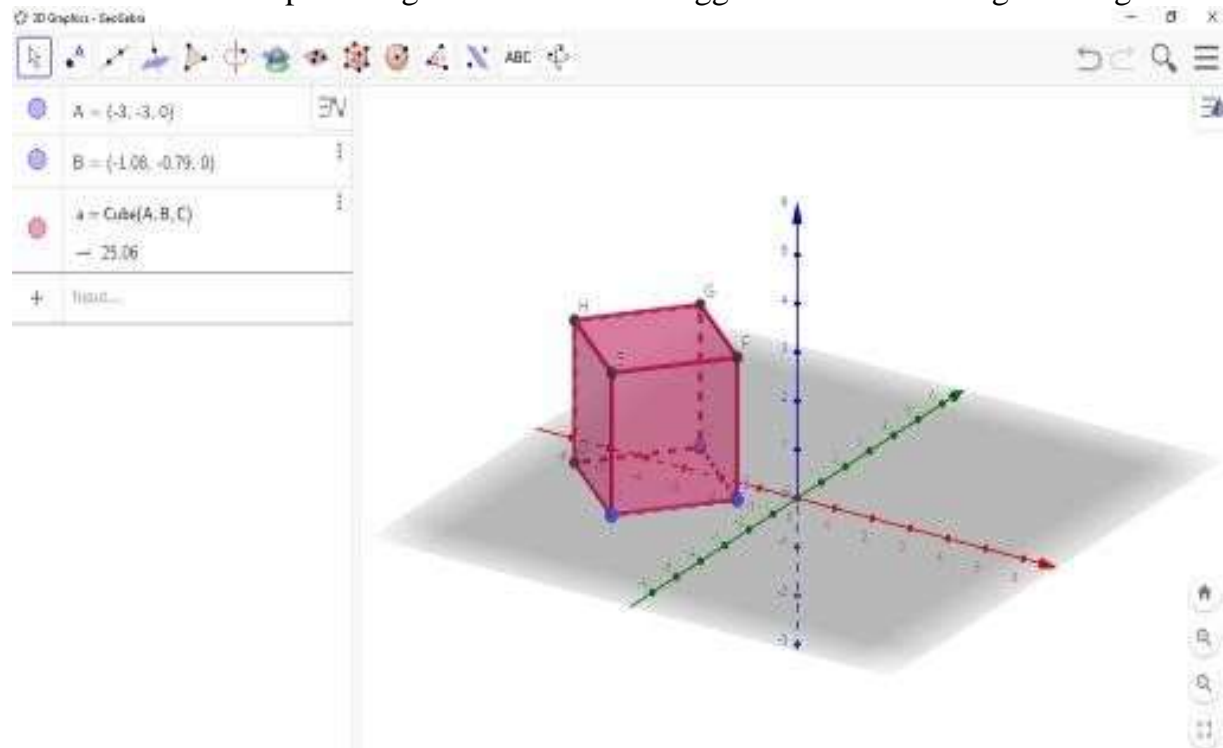

Gambar 1.3 Tampilan Bangun Kubus pada Geogebra Classic

Selain cara diatas, dapat juga menggunakan menu input yang ada di sebelah kirisehingga dapat memasukan koordinatnya atau titik-titiknya sesuai dengan keinginankita. Untuk mempermudah dalam melihat bentuk bangun ruang, ketika sumbu tersebut juga dapat diputar-putar sesuai keinginan sehingga dapat lebih leluasa dalammenjelaskan bagian-bagian dari bangun ruang tersebut.

a. Balok.

1)Klik pada point A kemudian klik point seperti tampilan pada gambar dibawah ini. Lalu tentukan 4 titik untuk membentuk bangun persegi panjang serta hubungkan ke-4titik tersebut menggunakan segment. 
ISSN. 2621-9832

JURNAL MathEdu (Mathematic Education Journal) http://journal.ipts.ac.id/index.php/MathEdu Vol. 4 No. 2 Juli 2021

Q Gescebraclosac

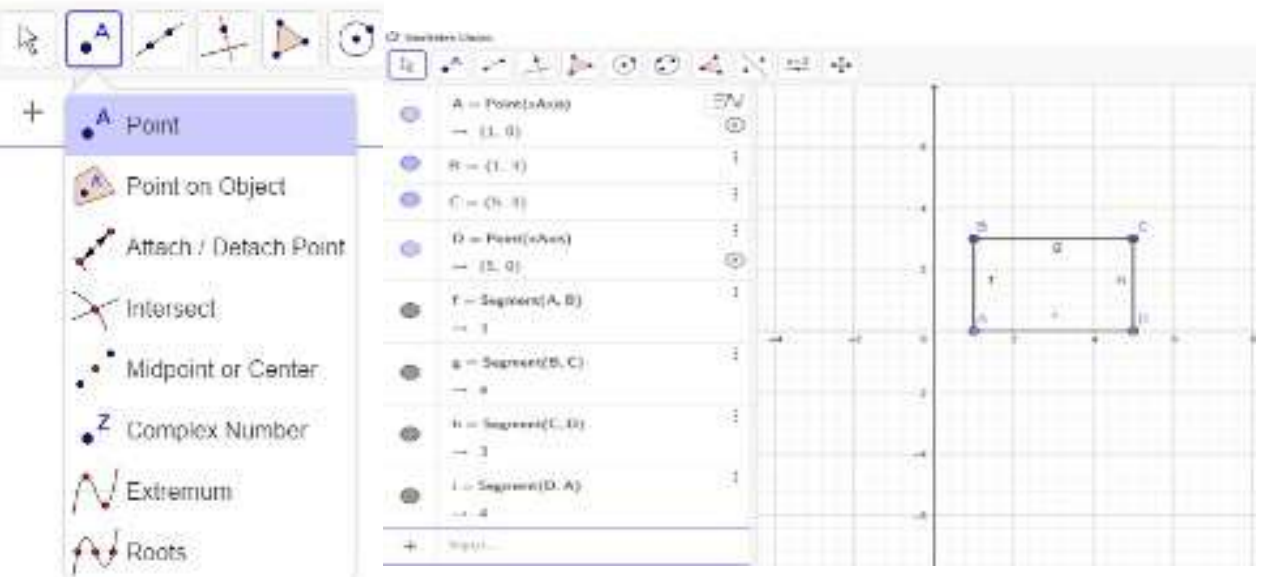

Gambar 1.4 Langkah Menggambar Balok

2) Bentuk persegi panjang menggunakan polygon pada gambar 10a lalu hubungkan ke empat titik.

$$
\text { Relygon }
$$

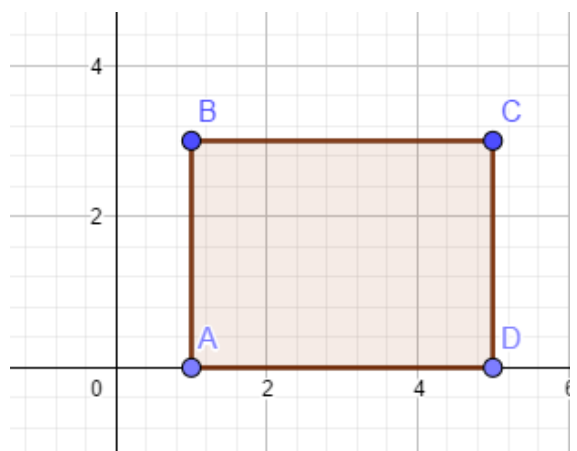

\section{Gambar 1.5 Menggunakan Polygon}

3)Buka lembar kerja 3D dengan klik 3D Graphich dan hilangkan grid pada lembarkerja 2D.

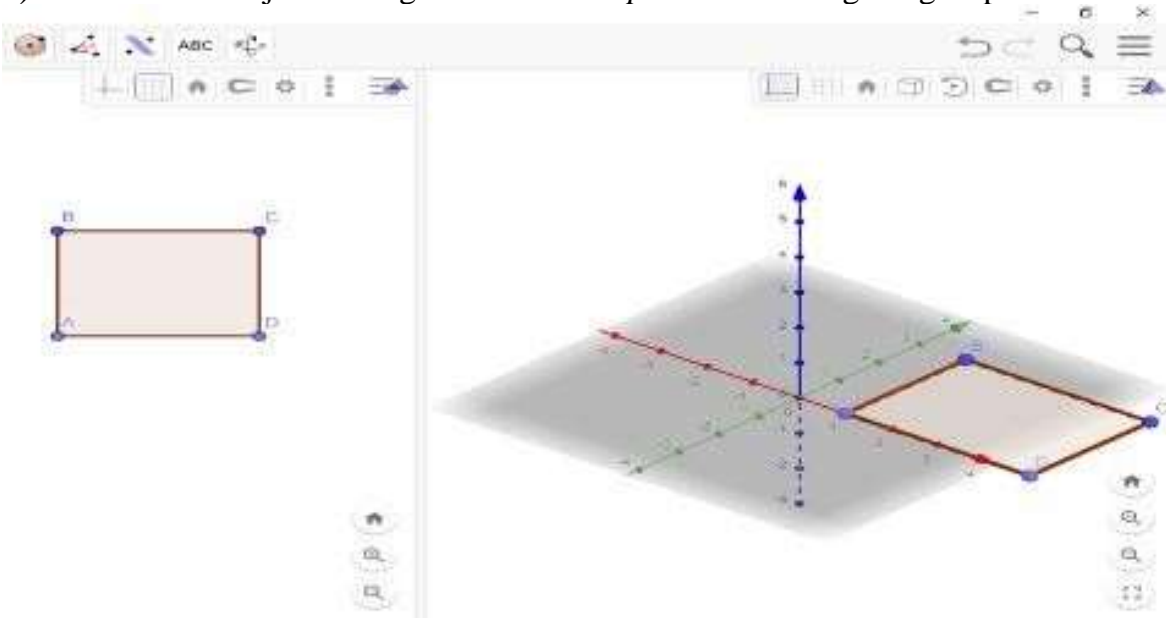

Gambar 1.6 Tampilan lembarkerja 2D dan 3D

4)Klik Extrude to Prism untuk membentuk bangun ruang balokdan masukkan tinggi balok yang diinginkan. Pada gambar ini tinggi balok 3 , maka akan muncul seperti gambar sebagai berikut. 
ISSN. 2621-9832

JURNAL MathEdu (Mathematic Education Journal) http://journal.ipts.ac.id/index.php/MathEdu Vol. 4 No. 2 Juli 2021

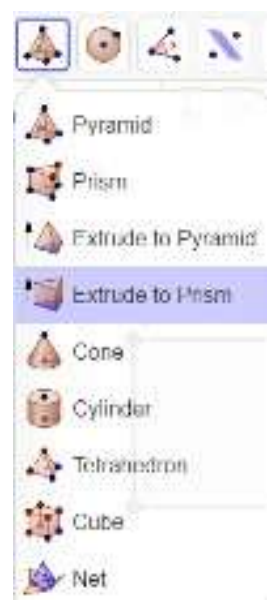
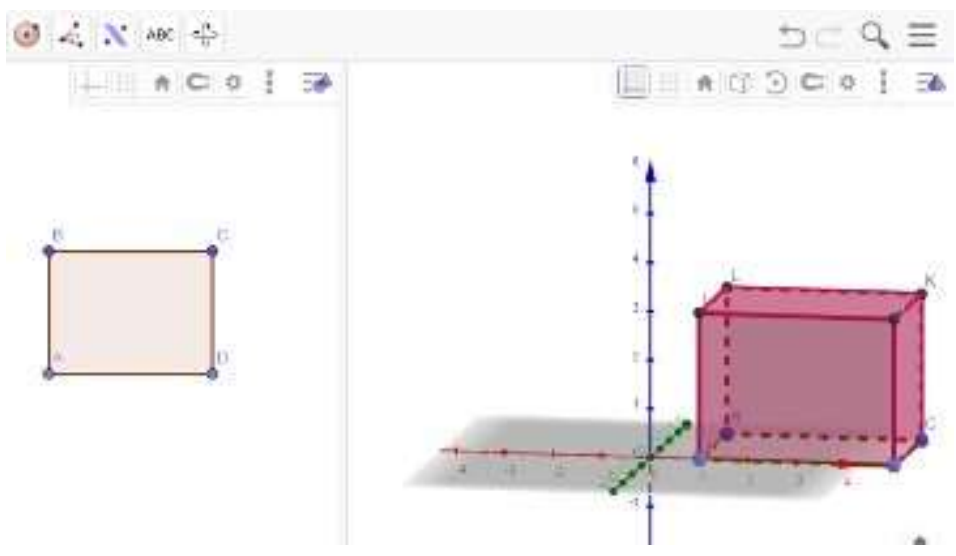

\section{Gambar 1.7 Menggunakan Extrude to Prism}

5) Jika akan menampilkan jarring-jaring balok, maka dapat klik "net" pada tampilangambar 1.7 kemudian klik balok sehingga akan muncul jarring-jaring balok seperti pada gambar dibawah ini.
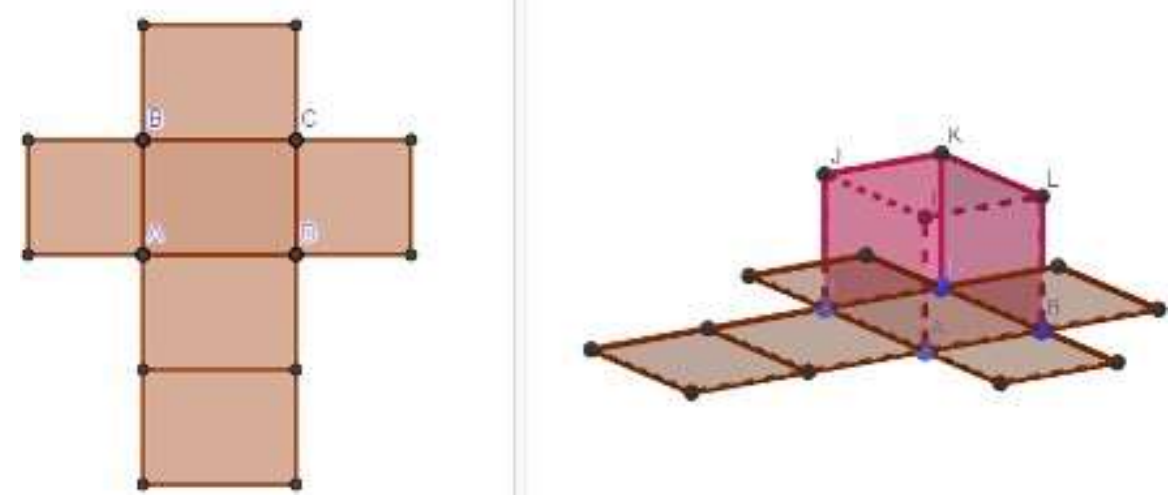

Gambar 1.8 Jaring-Jaring Balok

6)Untuk mendemonstrasikan jaring-jaring tersebut membentuk suatu balok maka gesergeserkan slider sehingga jarring-jaring akan bergerak menutup membentuk balok.

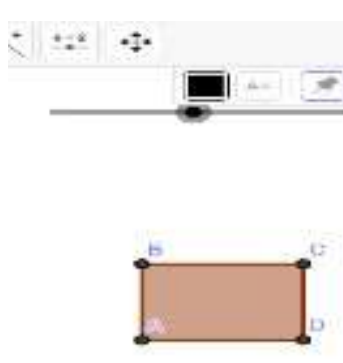

Gambar 1.9 Jaring-jaring Balok yang akan menutup membentuk Balok 
ISSN. 2621-9832

JURNAL MathEdu (Mathematic Education Journal) http://journal.ipts.ac.id/index.php/MathEdu

Vol. 4 No. 2 Juli 2021

Kelebihan GeoGebra menurut Umayah dan Evendi (2018) :

1. Free, dapat digunakan di berbagai sistem operasi (Windows, MacOS, Linux). Didukung lebih dari 40 bahasa. Dan berita baiknya bahasa Indonesia termasuk di dalamnya.

2. Publish WebFile .ggb. GeoGebra dapat dipublish sebagai web. Ini memudahkan siswa untuk menggunakanya karena cukup menggunakan browser (IE, Mozilla,Chrome, dll) untuk berinteraksi. Dengan kata lain pada komputer siswa tidakharus terinstal GeoGebra namun harus ada Java versi terbaru.

3. Easy to use. Setiap tombol dan sintaks pada GeoGebra selalu disertai dengan instruksi dan bantuan penggunaan.

4. Objek dapat digeser, dicerminkan, diputar dan diperbesar.

5. Fitur yang lengkap untuk pembelajaran matematika.

6. Dapat disalin ke dalam aplikasi Microsoft Office dan diekspor dalam beragam format.

7. Menghasilkan lukisan-lukisan geometri dengan cepat dan teliti jika dibandingkan dengan menggunakan pensil, penggaris, atau jangka.

8. Adanya fasilitas animasi dan gerakan-gerakan manipulasi (dragging) dapat memberikan pengalaman visual kepada siswa secara lebih jelas dalam memahami konsep geometri.

9. Dapat dimanfaaatkan sebagai evaluasi untuk memastikan bahwa lukisan yang dibuat sudah benar.

Kekurangan GeoGebra menurut Ardinata , dkk (2020) :

1. Materi yang dikembangkan terbatas pada materi dasar transformasi geometri (refleksi, translasi, rotasi, dan dilatasi).

2. Pembelajaran menggunakan media GeoGebra saat ini hanya bisa digunakan melalui laptop atau komputer. 
2. Matlab

Matlab (Matrix Laboratory) merupakan software yang dapat digunakan dalam bidang pendidikan yaitu untuk mengajar aljabar linier, analisis numerik, diagra, bangun ruang dan lain sebagainya (Syaharudin dan Abdila, 2018). Matlab R2018a merupakan software yang dapat digunakan sebagai media dalam pembelajaran bangun ruang. Software ini juga dapat digunakan untuk mengilustrasikan dan menampilkan bentuk dari suatu bangun ruang, sehingga guru akan lebih mudah dalam menjelaskan materi kepada siswa. Selain itu juga dapat mempermudah siswa dalam memahami dan membayangkan bangun ruang itu sendiri yang termasuk dalam bentuk 3D serta tergolong abstrak untuk dibayangkan (Lia Anggreni, 2020).

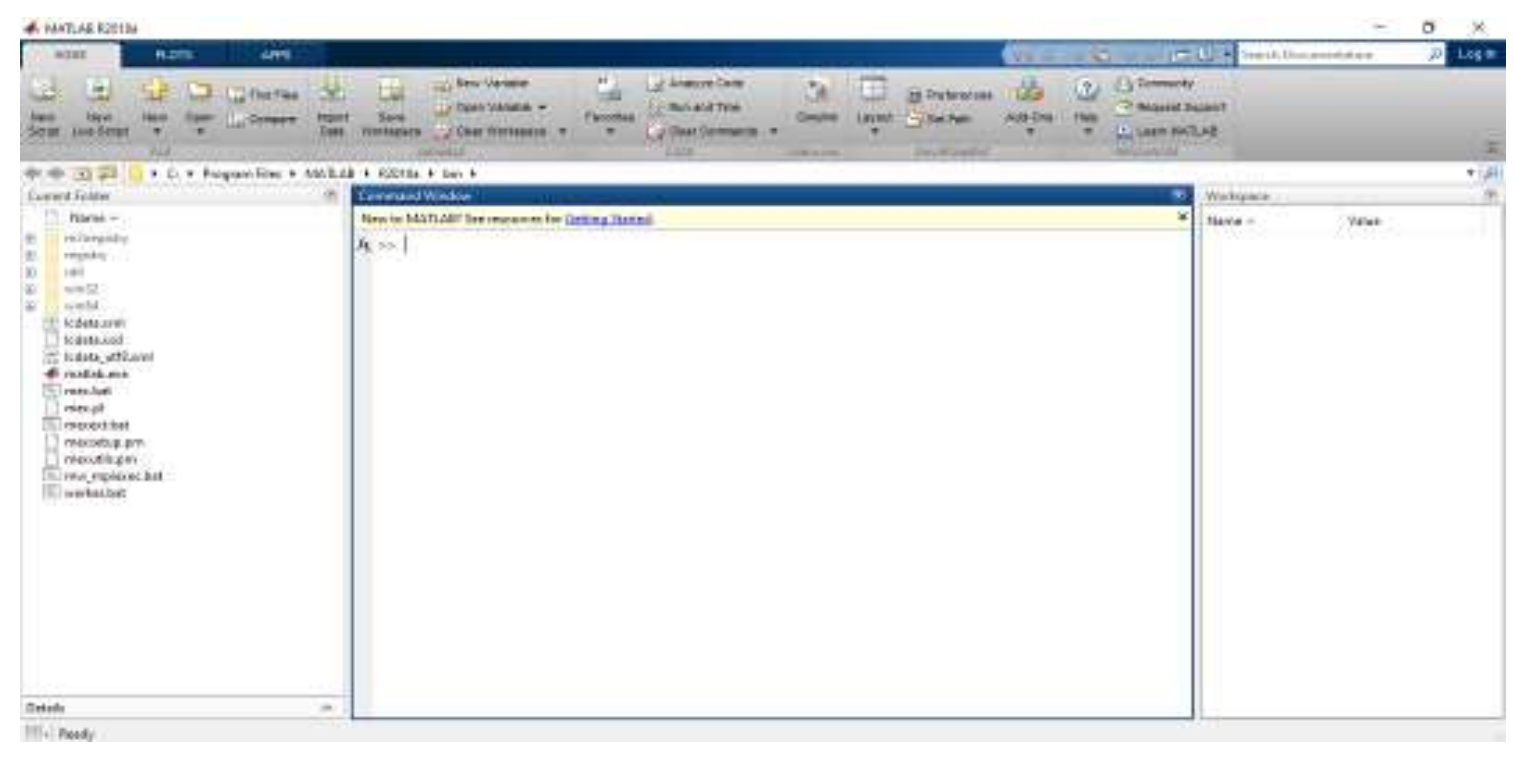

\section{Gambar 2.1 Jendela utama pada Matlab R2018a}

Tampilan awal pada saat membuka Matlab seperti pada Gambar 2.1 yang terdiri dari tiga kolom utama yaitu (Lia Anggreni, 2020) :

a. Current Folder

Di sini merupakan tempat unruk menyimpan file matlab yang sudah dibuat serta dapat juga untuk mengaktifkan atau mengakses file-file yang sudah tersimpan sebelumnya. Artinya jika sudah pernah menyimpan suatu file kemudian saat mengerjakan hal tertentu namun membutuhkan file yang sudah kita buat sebelumnya maka dapat diaktifkan melalui menu ini.

b. Command Window

Command Window merupakan lembar kerja utama pada Matlab yang berfungsi untuk mengetikkan perintah dalam bentuh menghitung, memanggil fungsi, dan lain sebagainya yang akan dijalankan dalam program Matlab. Sebelum menuliskan perintah selalu diawali dengan tanda " $>>$ " atau disebut juga prompt. Jika akan mengetikan sesuatu namun belum muncul tanda prompt itu maka perintah yang diketikkan tidak bias dijalankan. Maka sebelum mengetikkan perintah perhatikan dulu apakah tanda tersebut sudah muncul atau belum.

c. Workspace

Workspace (ruang kerja) berfungsi untuk menyimpan semua variable yang sudah dijalankan di Command window. Disini semua variable dari awal kita melakukan perintah akan tersimpan di workspace.

Selain tiga menu diatas, Matlab juga menyediakan menu Help yang berisikan tutorial menggunakan matlab. Cara menggunakannya yaitu dengan menekan pada toolbar atau mengetik 'helpwin' pada comment window (Budi Cahyono, 2013). Menu ini, berisikan segala macam informasi yang dapat dijalankan dalam program Matlab, sehingga menu ini sangat membantu jika sedang menjalankan program dan mengalami kesulitan. Menggunakan aplikasi Matlab dalam pembelajaran bangun ruang sangat efektif dan efisien karena kita tinggal mengoperasikannya saja. Berikut langkah-langkah membuat bangun ruang menggunakan Software Matlab R2018a (Sahyar, 2016), antara lain : 
ISSN. 2621-9832

JURNAL MathEdu (Mathematic Education Journal) http://journal.ipts.ac.id/index.php/MathEdu Vol. X . No. X Mounth 20XX

a. Membuat Kubus

Koding yang di gunakan :

$>$ colormap (cool);

>> cylinder $(4,4)$;

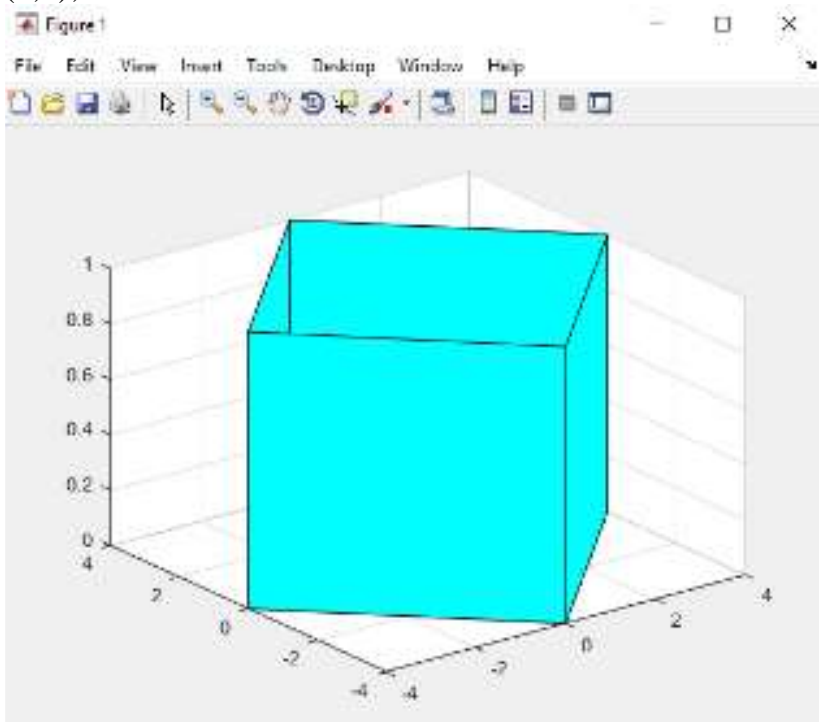

Gambar 2.2 Bangun Kubus

b. Membuat Tabung

Koding yang digunakan :

> cylinder $(30,30)$

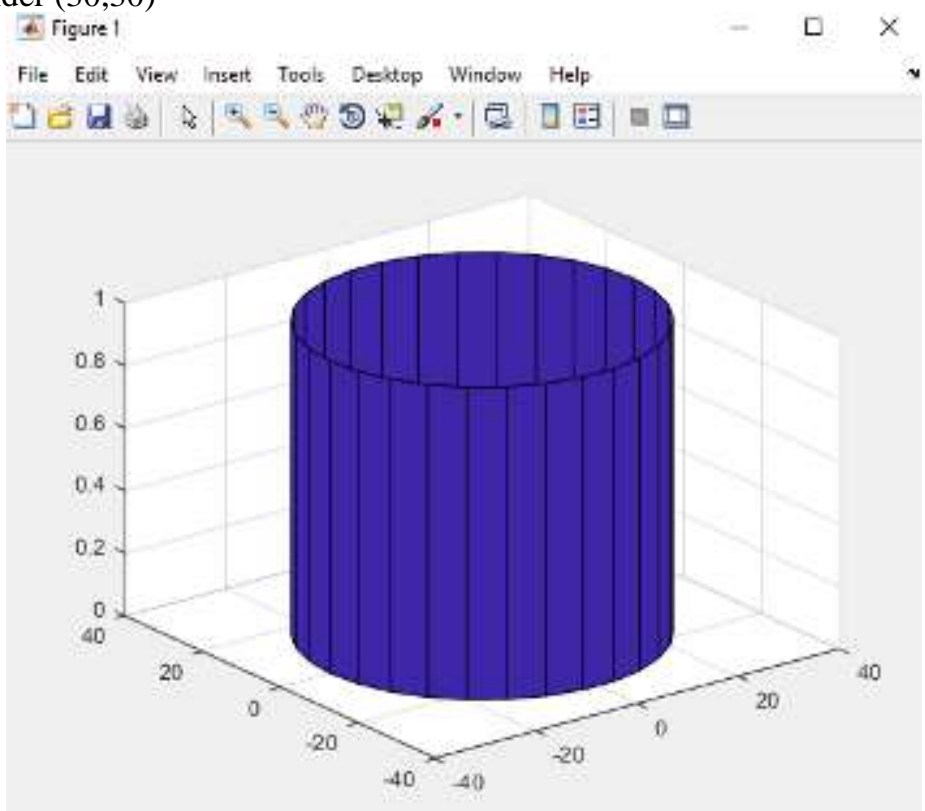

Gambar 2.3 Bangun Ruang Tabung

c. Membuat Bola

Koding yang digunakan :

>> sphere (30)

Atau

>> sphere (20)

Keterangan :

Angka 30 dan 20 menunjukkan banyaknya $\mathrm{N}$ dalam membuat bola. 


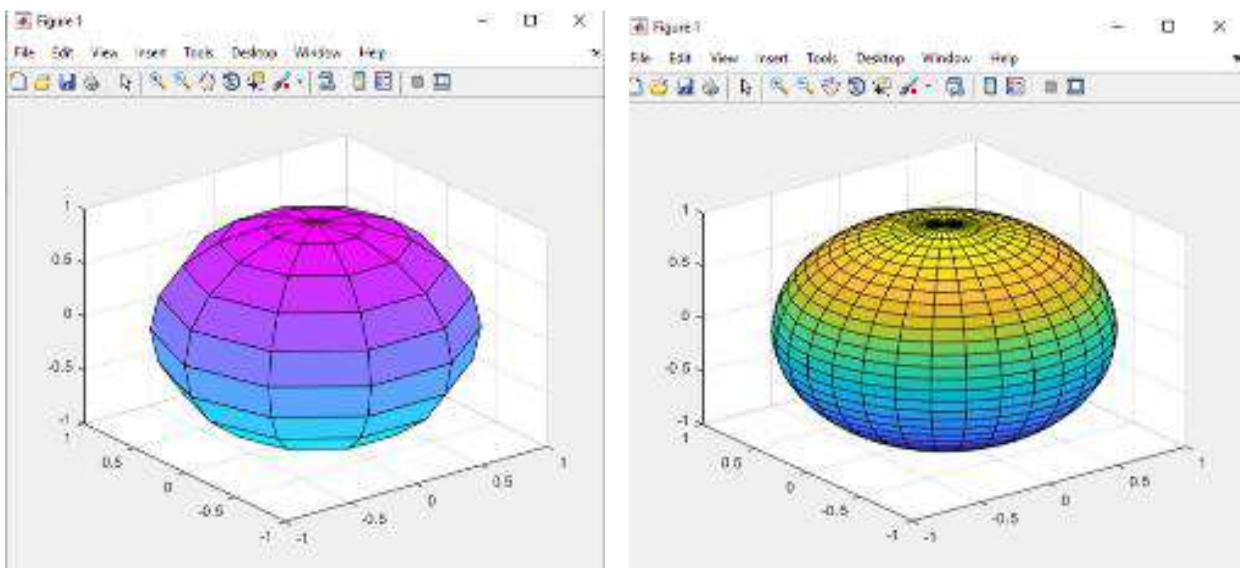

Gambar 2.4 Bola dengan $\mathrm{N}=30$ dan $\mathrm{N}=20$

Software Matlab sangat membantu dalam meningkatkan kemampuan komunikasi matematis siswa serta dapat meningkatkan minat belajar siswa dibandingkan hanya pembelajaran langsung tanpa menggunakan bantuan software Matlab (Hendra Kartika, 2014). Menggunakan Matlab dalam pembelajaran matematika, maka siswa dapat lebih mudah dan cepat memahami suatu konsep materi yang siajarkan (Budi Cahyono, 2013).

\section{Wingeom}

Program Wingeom (Window Geometry) merupakan salah satu perangkat lunak komputer matematika dinamik (dynamic mathematic software) untuk topik geometri. Wingeom me-rupakan salah satu bagian software gratis yang disebut Peanut Software. Software Wingeom diciptakan oleh Dr. Richard Parris, pengajar di Akademi Phillips Exeter, New Hampsire. Software Peanut (akronim yang dibentuk dari huruf pertama Phillips Exeter Academy) mulai diteliti sekitar tahun 1985. Program ini pada awalnya menggunakan bahasa pemrograman PASCAL, tetapi pada versi terakhir telah menggunakan $\mathrm{C}++$. Program geometri pertama dinamakan GEOM. Gagasan untuk membuat program mengenai geometri berasal dari Dick Brown, yang sebelumnya melihat Geometric Supposer untuk Apple II yang diciptakan oleh Judah Schwartz. Setelah menciptakan software menurut versinya sendiri, Dr. Parris menemui Judah Schwartz di konferensi musim panas Anja S. Greer yang diadakan di Exeter, dan dia mendapatkan ide untuk menyempurna-kan software ciptaannya, dan akhirnya menjadi Wingeom (Talmadge, 2002). Software ini bersifat open source, artinya dapat digunakan secara gratis dan tampilannya dapat disesuai-kan dengan yang kita inginkan. Software ini juga memiliki besar file yangtidak sampai lebih dari satu megabyte, serta kompatibel dengan semua jenis Window mulai dari Window95 sampai dengan Window7 (Rudhito, 2008).

Tampilan layar program Wingeom cukup sederhana, seperti tampak pada Gambar 1 di bawah ini. Seperti yang Anda lihat pada Gambar 1. Layar utama Wingeom memuat dua menu utama, yaitu Window dan Help. Menu Window memuat beberapa submenu, yaitu (Rudhito, 2008): 1. 2-dim, membuka program Wingeom untuk geometri dimensi dua.

2. 3-dim, membuka program Wingeom untuk geometri dimensi tiga.

3. Hyperbolic, membuka program Wingeom untuk geometri hiperbolik.

4. Spherical, membuka program Wingeom untuk geometri bola.

5. Voronoi, membuka program Wingeom untuk diagram voronai.

6. Guess, membuka program Wingeom untuk memprediksi macam-macam transformasi yang mungkin dengan menggunakan dua buah segitiga.

7. Tesselation, membuka program Wingeom untuk menampilkan macam-macam pengubinan dari bangun-bangun geometri dimensi dua.

8. $R G B$ demo, membuka program Wingeom untuk simulasi pen-campuran warna RGB.

9. Open last, membuka file yang terakhir dibuka saat program dijalankan kembali.

10. Use default, mengembalikan tampilan ke settingan awal. 
ISSN. 2621-9832

JURNAL MathEdu (Mathematic Education Journal) http://journal.ipts.ac.id/index.php/MathEdu Vol. X . No. X Mounth 20XX

11. Exit, keluar dari program Wingeom.

Menu Help terdiri dari submenu help, tips, dan about. Submenu help berisi tentang keterangan pengguna-an program secara umum, submenu tips menampilkan tip-tip dalam menjalankan program Wingeom, sedangkan submenu about berisi tentang informasi identitas dan sumber program Wingeom. Berikut disajikan beberapa contoh penerapan aplikasi Wingeom (Rudhito, 2008).

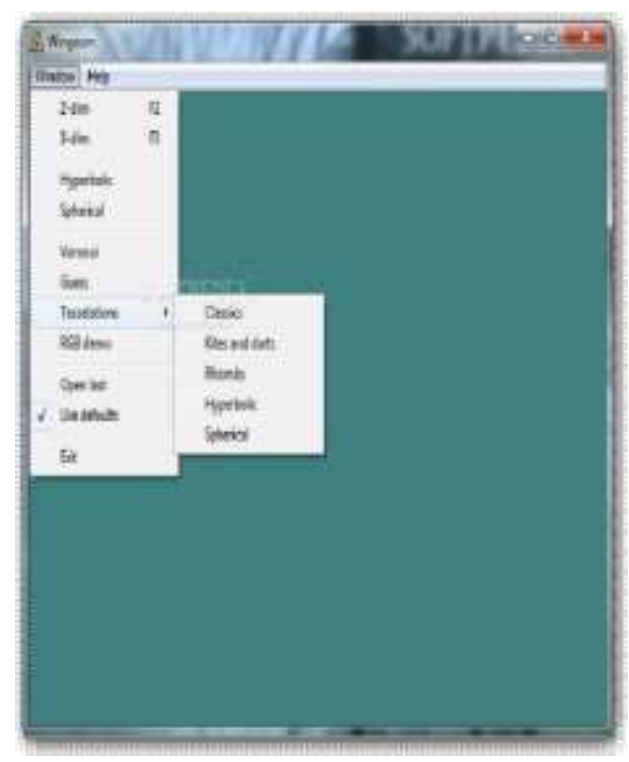

Gambar 3.1 Tampilan jendela Wingeom

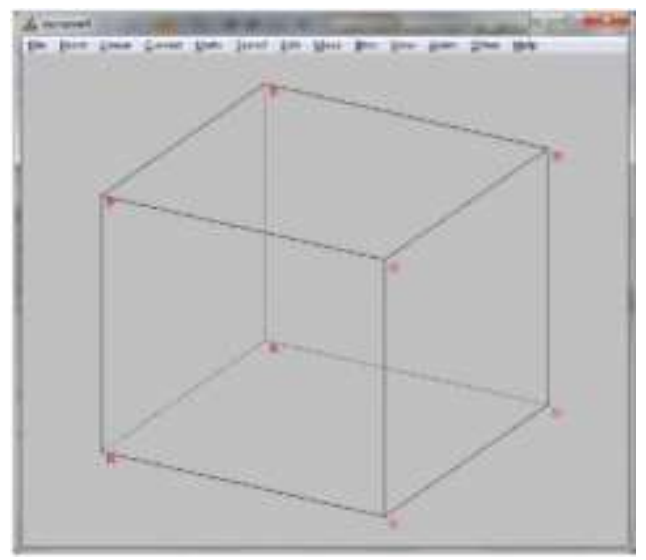

Gambar 3.2 Menggambar Kubus 
ISSN. 2621-9832

JURNAL MathEdu (Mathematic Education Journal) http://journal.ipts.ac.id/index.php/MathEdu Vol. X . No. X Mounth 20XX

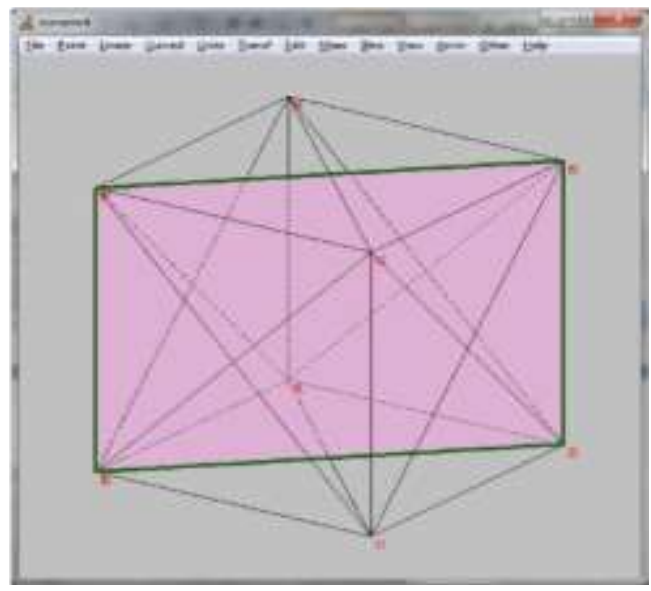

Gambar 3.3 Menggambar Garis Diagonal Bidang dan Bidang Diagonal

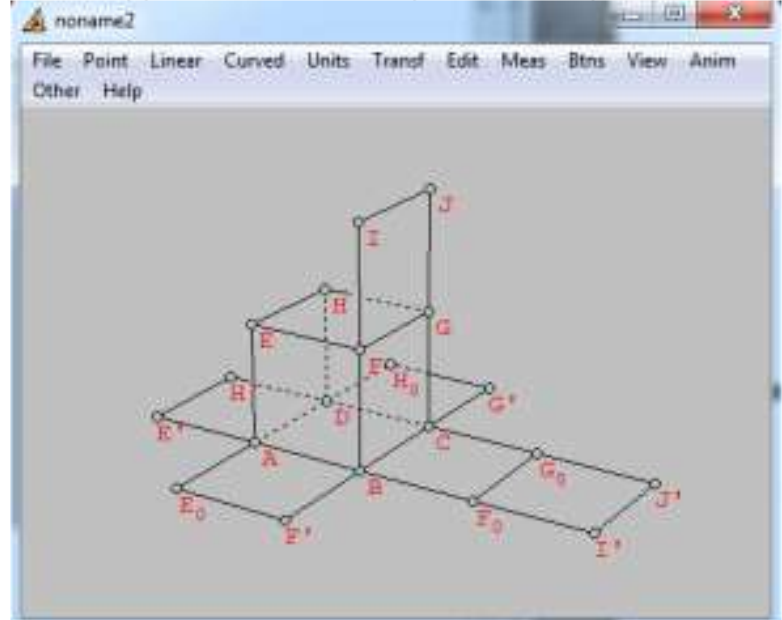

Gambar 3.4 Menyusun Animasi Jaring-jaring Kubus

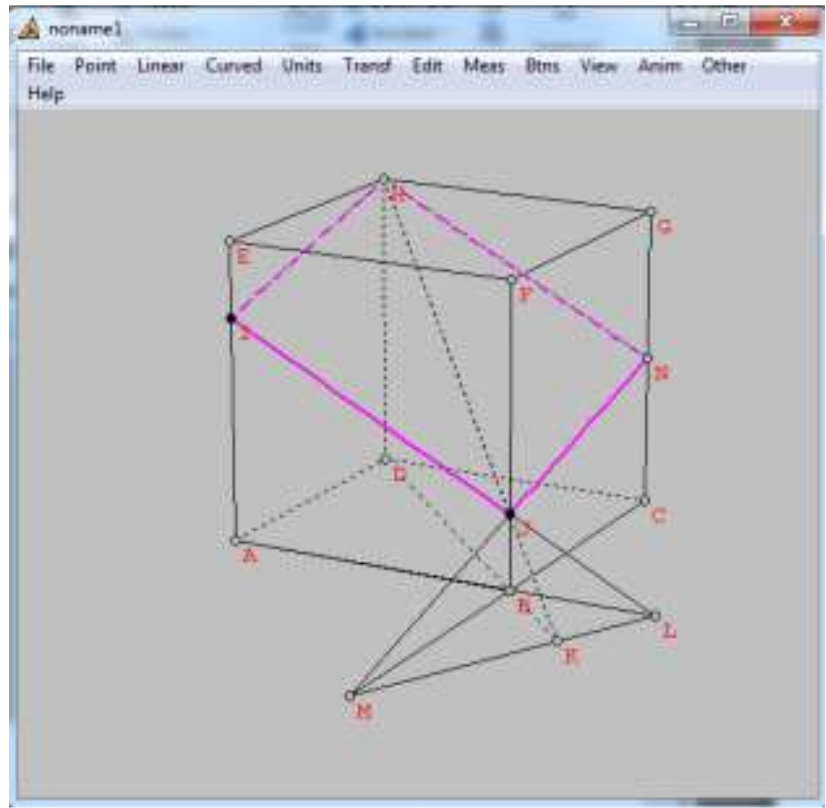

Gambar 3.5 Menggambar Irisan pada Kubus

Program Wingeom dapat membantu memvisualisasikan suatu konsep geometri dengan jelas sehingga mahasiswa akan lebih mudah memahami konsep-konsep geometri. Dengan program Wingeom, mahasiswa dapat mengeksplorasi, mengamati, melakukan animasi bangunbangun dan tampilan materi geometri (Pratiwi \& Septia, 2016). 


\section{Microsoft Math 3.0}

Microsoft Math adalah program edukasi, dibuat untuk sistem operasi Microsoft Windows, yang membantu pengguna untuk menyelesaikan permasalahan matematika dan sains. Aplikasi ini dibangun dan diprakarsai oleh Microsoft, dimana secara pokok ditargetkan untuk siswa sebagai alat bantu belajar. Microsoft Math 3.0 merupakan software baru yang dapat membantu siswa dalam menyelesaikan tugas matematika dan sains dengan lebih cepat dan mudah dalam mengajarkan konsep dasar yang penting. Fitur Microsoft Math 3.0 mampu membantu siswa menyelesaikan permasalahan yang kompleks pada alajabar dasar, aljabar, trigonometri, kalkulus, fisika dan kimia. Dengan menggunakan Microsoft Math 3.0 siswa dapat menyelesaikan persamaan tahap demi tahap sambil memperoleh suatu pemahaman yang lebih baik mengenai konsep dasar tersebut. Tampilan dari Microsoft Math 3.0 adalah seperti gambar berikut (Andriani, 2009).

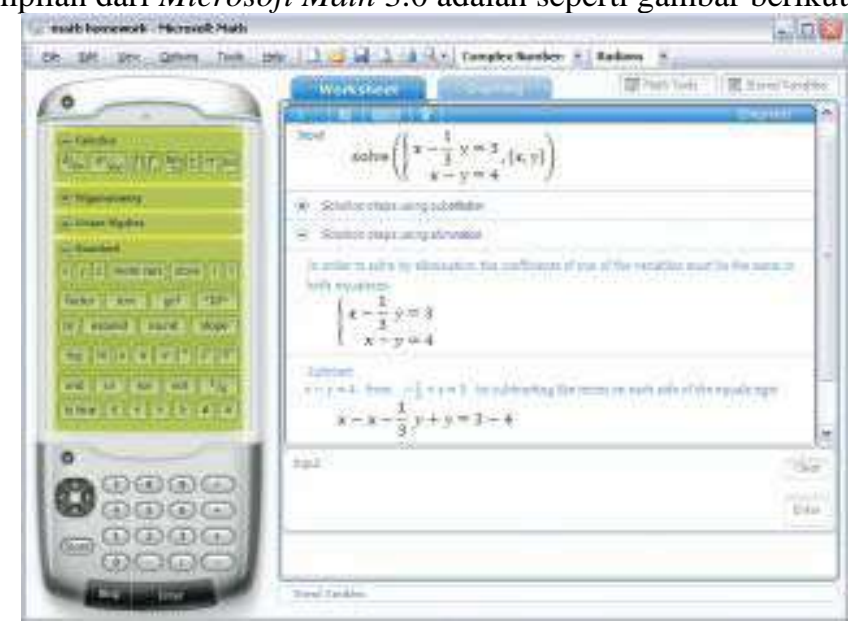

Gambar 4.1 Tampilan awal Microsoft Mathematics 4.0

Fitur-fitur yang terdapat dalam Microsoft Math 3.0 antara lain (Andriani, 2009):

a. Graphing Calculator. Didesain untuk membantu siswa memvisualisasi dan menyelesaikan permasalahan matematika dan sains yang rumit.

b. Step by step Equation Solver. Fitur ini memberikan siswa penyelesaian tahap demi tahap berbagai permasalahan matematika.

c. Formulas and Equation Library. Berisi lebih dari 100 persamaan-persamaan dan rumus-rumus yang dapat ditemukan dengan cepat dan mudah.

d. Triangle Solver. Fitur ini merupakan suatu perangkat grafis yang dapat membantu siswa mengeksplorasi segitiga dan memahami hubungan antara komponen pada segitiga.

e. Unit Conversion Tool. Dapat digunakan oleh siswa untuk mengkonversi unit ukuran seperti: panjang, luas, volume, berat, suhu, tekanan, daya, kecepatan dan waktu.

f. Ink Handwriting Support. Cara kerja fitur ini mirip dengan Tablet PC, dimana siswa menulis permasalahan yang akan diselesaikan dengan tangan (bantuan mouse) yang kemudian disesuaikan oleh Microsoft Math 3.0.

Fitur-fitur yang terdapat dalam Microsoft Math 3.0 sangat bermanfaat dalam proses pembelajaran matematika. Pengoperasiannya sangat sederhana tanpa menggunakan bahasa pemrograman seperti Matlab, Maple, Fotrlan, dan Cabri. Aplikasi ini memang didesain instan untuk membantu siswa menyelesaikan tugas-tugas yang berkaitan dengan matematika dan sains. Melalui aplikasi ini memungkinkan siswa dapat mencoba sendiri menyelesaikan permasalahan matematika dengan berbagai alat bantu yang tersedia. Di samping itu siswa juga dapat lebih memahami konsep dasar secara lebih komprehensif karena didukung oleh tampilan grafis yang detail dan menarik. Dengan kata lain, aplikasi ini sangat mendukung untuk pembelajaran dengan pendekatan konstruktivis, dimana siswa diarahkan untuk menemukan sendiri konsep matematika berdasarkan pemahaman awal yang mereka miliki.

Berbagai topik permasalahan dalam matematika yang dapat diselesaikan dengan Microsoft Math 3.0. Misalkan siswa akan diajarkan tentang konsep persamaan linier. Pembelajaran dimulai dengan mengarahkan siswa mengekspolasi grafik persamaan linier $y=m x$ $+b$. Tahap-tahap pembelajaran adalah sebagai berikut (Andriani, 2009): 
JURNAL MathEdu (Mathematic Education Journal) http://journal.ipts.ac.id/index.php/MathEdu

Vol. X . No. X Mounth 20XX

1. Membuat grafik $y=m x+b$ pada Microsoft Math 3.0 dengan menggunakan fitur Graphing Calculator. Caranya ketik persamaan $y=m x+b$ pada baris pertama dalam functions kemudian pilih enter dan pilih graph. Maka akan muncul grafik $y=m x+b$.

2. Pada grap control, atur animate pada nilai $m$ dan $b$ dari -2 sampai 2 dengan mengetik lower bound dan upper bound.

3. Siswa dapat memanipulasi nilai $m$ dan $b$ pada graph control.

4. Siswa diminta mengindentifikasi grafik jika $b=-2, \mathrm{i}=0$ atau $b=1$

5. Siswa diminta mengindentifikasi grafik jika $m=-2, m=0$ atau $m=1$

6. Arahkan siswa untuk menyimpulkan apa yang mereka peroleh.

7. Langkah selanjutnya adalah menggambar persamaan $y=2 x-1$ pada sumbu yang sama. Caranya ketik persamaan pada baris kedua dalam functions kemudian pilih enter dan graph.

8. Atur nilai $m$ dan $b$ pada persamaan $y=m x+b$ sehingga berimpit dengan persamaan $y=2 x-1$. Atur display lebih besar agar tampilan grafik jelas. Berapa nilai $\mathrm{m}$ dan $\mathrm{b}$ sehingga kedua grafik tersebut berimpit?

9. Selanjutnya atur nilai $m$ dan $b$ persamaan $y=m x+b$ sehingga kedua grafik sejajar. Berapa nilai $m$ dan $b$ sehingga kedua grafik sejajar? Apakah terdapat lebih dari satu alternatif jawaban? Jelaskan mengapa?

10. Atur nilai $m$ dan $b$ pada persamaan $y=m x+b$ sehingga berpotongan dengan persamaan $y=$ $2 x-1$. Atur display lebih besar agar tampilan grafik jelas. Berapa nilai $m$ dan $b$ sehingga kedua grafik tersebut berpotongan? Apakah ada alternatif jawaban yang lain?

11. Siswa diarahkan untuk membuat kesimpulan mengenai kondisi yang terjadi jika parameter $\mathrm{m}$ dan b pada persamaan $y=m x+b$ diubah-ubah. Kapan dua garis dikatakan berimpit, sejajar dan berpotongan.

Langkah-langkah pembelajaran di atas merupakan contoh sederhana pemanfaatan Microsoft Math 3.0 dalam pembelajaran matematika. Siswa dapat melakukan sendiri manipulasi grafik dengan tampilan yang diinginkan. Proses konstruksi konsep menjadi lebih mudah dan cepat serta kreatifitas siswa pun menjadi lebih terasah. Permasalahan matematika yang berkaitan dengan kehidupan sehari-hari untuk memperdalam pemahaman dapat diekspolasi setelah konsep dikonstruksi. Siswa dapat menggunakan Microsoft Math 3.0 dalam menyelesaikan masalah tersebut. Hasil kerja siswa dapat disimpan dalam bentuk Worksheet yang dapat dibuka kembali. Masih banyak fitur-fitur dalam Microsoft Math yang dapat dimanfaatkan untuk konsep lainnya seperti geometri, kalkulus, aljabar dan statistik. Aplikasi ini sangat sesuai dimanfaatkan oleh siswa maupun mahasiswa. Penggunaannya yang relatif mudah dapat dijadikan sebagai salah satu alternatif media dalam mendukung pembelajaran matematika yang lebih efektif dan bermakna(Andriani, 2009).

\section{Microsoft Math 4.0}

Salah satu program/software yang dapat digunakan agar siswa dapat memahami konsep matematika dengan baik serta membantu mereka dalam menyelesaikan permasalahan matematika yang kompleks adalah Microsoft Mathematics 4.0. Dengan menggunakan Microsoft Mathematics 4.0, guru tidak menjadi sumber utama dalam mengoreksi setiap langkah pekerjaan siswa, karena setelah siswa selesai mengerjakansoal secara manual, mereka dapat langsung mencocokkan jawabannya dengan jawaban yang ditampilkan oleh program tersebut (Suryacitra \& Oktavia, 2018).

Fitur-fitur yang terdapat dalam Microsoft Mathematics sangat bermanfaat dalam proses pembelajaran matematika. Pengoperasiannya sangat sederhana tanpa menggunakan bahasa pemrograman seperti Matlab, Maple, Fotrlan, dan Cabri (Auliya, et all., 2020). 
ISSN. 2621-9832

JURNAL MathEdu (Mathematic Education Journal) http://journal.ipts.ac.id/index.php/MathEdu Vol. X . No. X Mounth 20XX

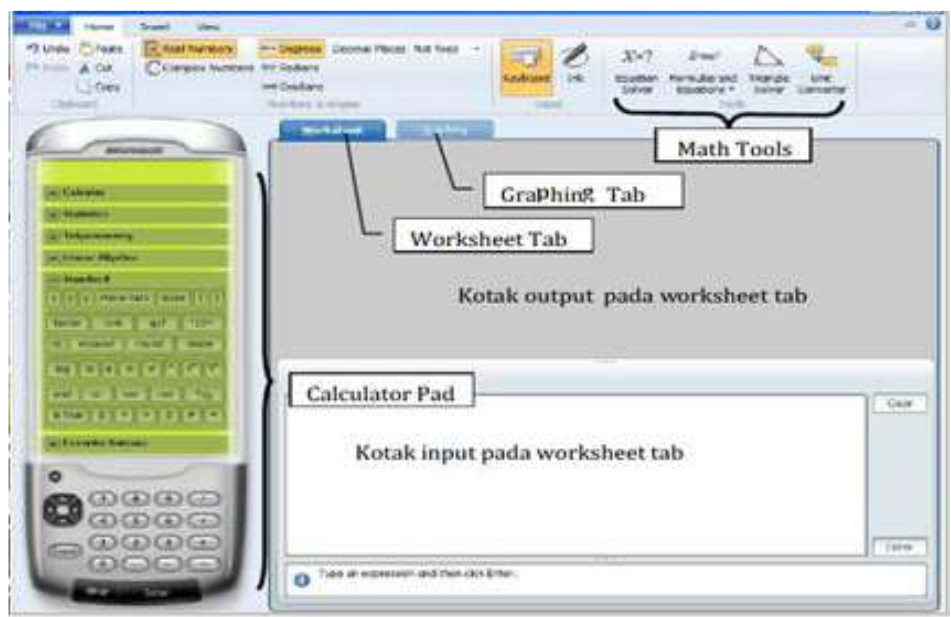

Gambar 5.1. Tampilan Awal Microsoft Mathematics

1. Calculator Pad, memuat pad angka dan kelompok tombol: Calculus, Statistics, Trigonometry, Linear Algebra, standard, dan Favorite Buttons.

2. Tab Woksheet, merupakan tempat untuk melakukan perhitungan numerik. Tab ini memuat kotak input dan output.

3. Tab Graphing, digunakan untuk pembuatan grafik. Tab ini memuat kotak input untuk memasukkan persamaan fungsi, kumpulan data, persamaan parametrik atau ketaksamaan yang akan dibuat grafiknya.

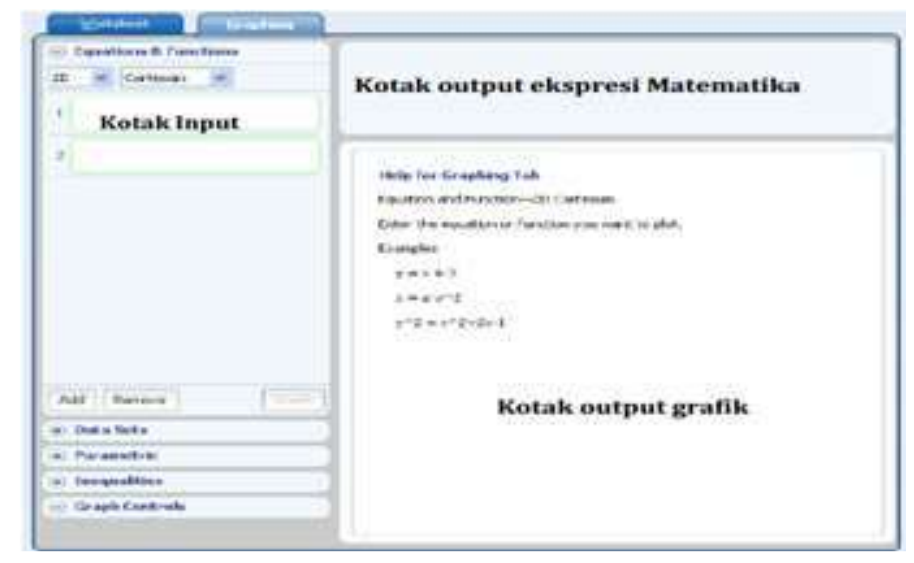

Gambar 5.2. Tampilan Tab Graphing

4. Math Tools, terdiri dari :

a. Equation Solver, digunakan untuk menyelesaikan persamaan tunggal atau sistem persamaan.

b. Formulas and Equation, untuk menemukan persamaan yang sering digunakan dalam matematika dan sains, serta menampilkannya dalam bentuk grafik atau menyelesaikannya.

c. Triangle Solver, untuk mengeksplorasi segitiga dan memahami hubungan antara komponen pada segitiga.

d. Unit Conversion Tool, untuk mengkonversi unit ukuran seperti: panjang, luas, volume, berat, suhu, tekanan, daya, kecepatan dan waktu.

5. Ink Handwriting Support. Cara kerja fitur ini mirip dengan Tablet PC, dimana siswa menulis permasalahan yang akan diselesaikan dengan tangan (bantuan mouse) yang kemudian disesuaikan oleh Microsoft Mathematics.

Berikut ini merupakan beberapa contoh penggunaan Microsoft Mathematics 4.0 dalam pembelajaran matematika di SMA/SMK (Auliya, et all., 2020):

1. Mencari turunan pertama dari suatu persamaan

Contoh: Tentukan turunan pertama dan kedua dari $\left(2 x^{2}-x\right)^{3}$.

Langkah-langkah penyelesaian: 
ISSN. 2621-9832

JURNAL MathEdu (Mathematic Education Journal) http://journal.ipts.ac.id/index.php/MathEdu Vol. X . No. X Mounth 20XX

a. Klik tab calculator $\rightarrow$ Calculus

b. Klik dan tuliskan pada kotak input dan tekan enter.

c. Pada kotak output akan muncul hasilnya.

\begin{tabular}{|l|}
\hline Input $\quad \frac{d}{d x}\left(\left(2 x^{2}-x\right)^{3}\right)$ \\
$\oplus$ Solutionsteps \\
Ourput $(12 x-3)\left(2 x^{2}-x\right)^{2}$ \\
\hline
\end{tabular}

\section{Gambar 5.3. Tampilan Kotak Output}

d. Untuk melihat tahapan penyelesaian, klik Solution steps, sehingga akan muncul:

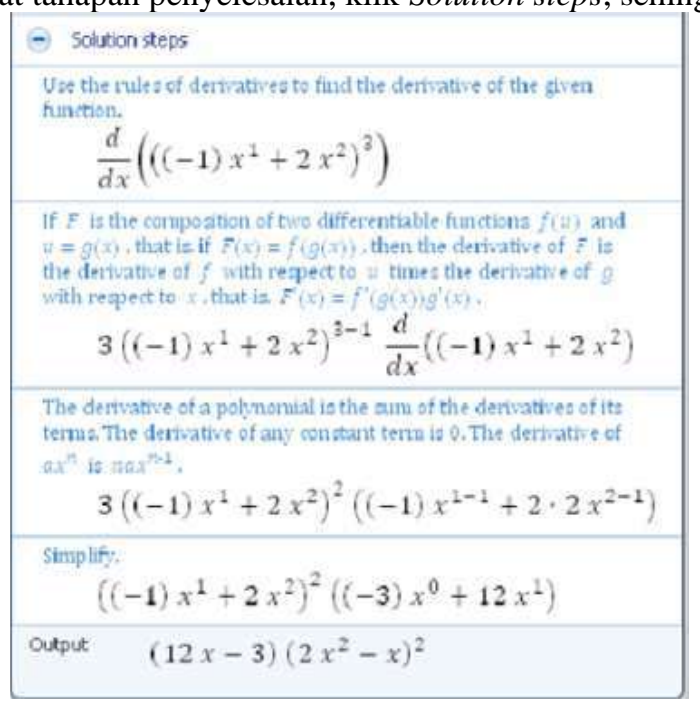

Gambar 5.4. Tampilan Penyelesaian

2. Menghitung nilai dari integral tentu dan tak tentu

Contoh: Tentukan integral dari $(12 \mathrm{x}-3)\left(2 \mathrm{x}^{2}-\mathrm{x}\right)^{2}$.

Langkah-langkah penyelesaian:

a. Klik tab calculator $\rightarrow$ Calculus

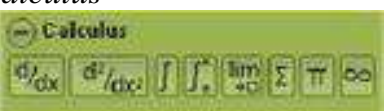

Gambar 5.5. Tampilan Tab Calculus

b. Klik lambang integral dan tuliskan $(12 \mathrm{x}-3)\left(2 \mathrm{x}^{2}-\mathrm{x}\right)^{2}$ pada kotak input dan kemudian tekan enter.

c. Pada kotak output akan muncul

\begin{tabular}{ll}
\hline Input & $\int(12 x-3)\left(2 x^{2}-x\right)^{2} d x$ \\
output & $8 x^{0}-12 x^{5}+6 x^{4}-x^{3}+\mathrm{C}$ \\
\hline
\end{tabular}

Gambar 5.6. Kotak Output

d. Jika pada soal diketahui batas atas dan batas bawah integral maka dapat menggunakan tombol

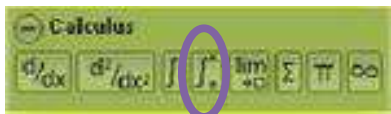




\section{Gambar 5.7. Integral yang menpunyai batas}

3. Membuat grafik 2D dengan koordinat polar

Contoh: Gambarlah grafik 2D dari $r=a \cos (k \sigma+b)$.

Langkah-langkah penyelesaian:

a. Klik tab Graphing

b. Pilih Equation Functions.

c. Pilih $2 D$ pada daftar dimensi.

d. Pilih Polar pada daftar koordinat.

e. Tuliskan $a \cos (k \sigma+b)$ pada kotak input dan klik enter.

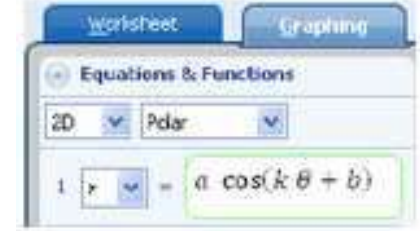

\section{Gambar 5.8. Tampilan Worksheet}

\section{f. Klik Graph}

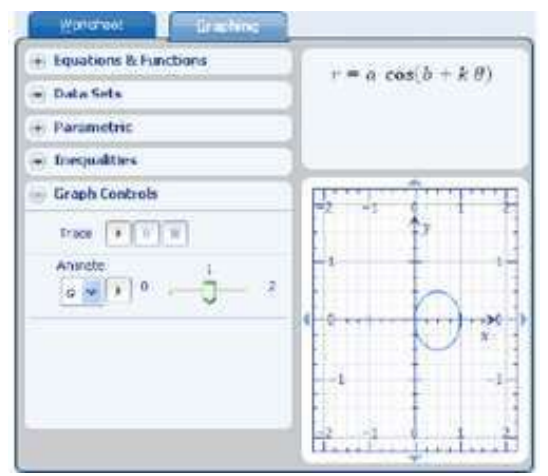

Gambar 5.9. Tampilan Graph

\section{KESIMPULAN}

Aplikasi merupakan program yang digunakan untuk menjalankan perintah - perintah yang bertujuan untuk mendapatkan hasil yang lebih akurat sesuai dengan tujuan pembuatan aplikasi tersebut. Pada zaman yang semakin canggih ini, dimana perkembangan teknologi sangat pesat, aplikasi dapat membantu manusia di berbagai bidang salah satunya di bidang pendidikan. Matematika merupakan mata pelajaran yang diajarkan di semua jenjang. Oleh karena itu dibutuhkan media pembelajaran yang interaktif dan up to date. Media pembelajaran berbasis teknologi yang biasa digunakan adalah komputer. Karena adanya pandemi Covid-19 berakibat salah satunya bidang pendidikan yang menyebabkan pembelajaran dilakukan secara daring. Dengan adanya aplikasi yang mendukung pembelajaran matematika guru maupun siswa dapat memanfaatkan aplikasi - aplikasi tersebut untuk memudahkan pmbelajaran apalagi pada masa pandemi ini.

\section{REFERENSI}

Afifah, D. S. (2012). Interaksi Belajar Matematika Siswa Dalam Pembelajaran Kooperatif Tipe STAD. Jurnal Pegagogia, I(2), 145-151.

Akhmadan, W. (2017). Pengembangan Bahan Ajar Materi Garis dan Sudut Menggunakan Macromedia Flash dan Moodle Kelas VII Sekolah Menengah Pertama. Jurnal Gantang, 2(1), 27-40.

Akkaya A, Tatar E, Kagizmanli, T B . (2011). Using Dynamic Software in Teaching of the Symmetry in Analytic Geometry: The Case of Geogebra . Procedia Social and Behavioral Sciences, 15 2540-2544.

Ardinata I Dewa Gede Putra, dkk (2020). Pengembangan GeoGebra untuk Materi Transformasi Geometri Berorientasi Strategi IKRAR dalam Upaya Meningkatkan Kemampuan Pemecahan Masalah Matematika. Jurnal Matematika, Sains, dan Pembelajarannya, Vol. 14 No 1, April 2020. 
Auliya Risma Nurul, dkk (2020). Pemanfaatan Microsoft Mathematics 4.0 dalam Pengembangan Pembelajaran Matematika di SMA/SMK. Jurnal pengabdian kepada Masyarakat, Vol.11 No.1.

Budi Cahyono. 2013. Penggunaan Software Matrix Laboratory (MATLAB) dalam Pembelajaran Aljabar Linier. Jurnal Phenomenon, 1(1), 45-62.

Crismono, P. C. (2017). Pengaruh Outdoor Learning Terhadap Kemampuan Berpikir Kritis Matematis Siswa. Jurnal Pendidikan Matematika dan Sains, IV(2), 106-113.

Hartinah DS, S. d. (2013). Sikap Guru Taman Kanak-Kanak Terhadap Pembelajaran Matematika. Jurnal Ilmu Pendidikan, 19(1), 50-55.

Hasan Abdurahman dan Asep Ririh Riswaya. 2014. Aplikasi Pinjaman Pembayaran Secara Kredit Pada Bank Yudha Bhakti. Jurnal Computech \& Bisnis, Vol. 8 No. 2.

Hendra Kartika. 2014. Pembelajaran Matematika Berbantuan Software Matlab sebagai Upaya Meningkatkan Kemampuan Komunikasi Matematis dan Minat Belajar Siswa SMA. Jurnal Pendidikan UNSIKA, 2(1), 24-35.

Hohenwarter M, Hohenwarter J, Kreis Y, Lavicza Z . (2008). Teaching and calculus with free dynamic mathematics software Geogebra. 11th International Congres Mathematical Educatin. Mexico.

Intan, A. (2018). Proses Pembelajaran Digital dalam Era Revolusi Era 4.0. Direktur Jenderal Pembelajaran dan Kemahasiswaan. Kementerian Riset, Teknologi, dan Pendidikan Tinggi.

Lia Anggreni (2020). Matlab R2018a Vs Geogebra Classic Terhadap Pembelajaran Bangun Ruang. Jurnal Pendidikan, 978-623-94501-0-6.

Lina Handayani (2020). Keuntungan, Kendala dan Solusi Pembelajaran Online Selama Pandemi Covid19 : Studi Ekploratif di SMPN 3 Bae Kudus. Journal Industrial Engineering \& Management Research ( Jiemar), Vol. 1 No. 2.

M. Pratiwi and T. Septia. (2016). Efektifitas Modul Aplikasi Komputer Dengan Program Wingeom pada Materi Geometri. LEMMA, vol. III, no. 1, pp. 97-107.

Mugrfuah, R.(2011). Meningkatkan kompetensi guru melalui penguasaan teknologi informasi dan komunikasi (TIK). Prodi Pengembangan Kurikulum. Universitas Pendidikan Indonesia. Sunan Kalijaga: Yogyakarta.

Nengrum Thityn Ayu, dkk (2021). Kelebihan dan Kekurangan Pembelajaran Luring dan Daring dalam Pencapaian Kompetensi Dasar Kurikulum Bahasa Arab di Madrasah Ibtidaiyah 2 Kabupaten Gorontalo. Jurnal Pendidikan, Vol. 30 No.1.

Parhaini Andriani (2009). Penggunaan Microsoft Math 3.0 Dalam Pembelajaran Matematika. Prosiding Seminar Nasional Penelitian.

Pakpahan Roida, Fitriani Y (2020). Pemanfaatan Teknologi Informasi dalam Pembelajaran Jarak Jauh DiTengah Pandemi Virus Corona Covid-19. Journal of Information System, Applied, Management, Accounting and Researh, Vol 4 No. 2.

Putri, I. A., \& Purwaningsi, B. E. 2020. Inovasi Pembelajaran Matematika (Grafik Fungsi)Dengan Geogebra Classic. In PROCEEDING.

Rudhito, M. A. (2008). Geometri dengan Wingeom. Yogyakarta: Universitas Sanata Dharma. 
ISSN. 2621-9832

JURNAL MathEdu (Mathematic Education Journal) http://journal.ipts.ac.id/index.php/MathEdu Vol. X . No. X Mounth 20XX

Sahyar, 2016. Algoritma dan Pemrograman Menggunakan MATLAB (Matrix Laboratory). Jakarta : Kencana.

Suryacitra, G. E., Oktavia, R. (2018). Pemanfaatan Program Microsoft Mathematics untuk Meningkatkan Ketelitian Siswa Kelas XI dalam Menyelesaikan Soal Perkalian Dua Buah Matriks. Prosiding Seminar Nasional Etnomatnesia, 647-653.

Syaharudin dan Abdila. 2018. 5 Software Sousi dan Simulasi Matematika. Yogyakarta : Deepublish.

Talmadge, A. (2002). Tech Talk "Wingeom: A No Cost Alternative for Computer Aided Geometry. University of New Orleans.

Umayah Y, Evendi H. (2018). Analisis Pemanfaatan Software Geogebra untuk Meningkatkan Motivasi Belajar Siswa dalam Pembelajaran Matematika. Jurnal Mitra Pendidikan Online, Vol 2, No. 4, 446-455. 